\title{
Synchronization of cell division in eight-cell bovine embryos produced in vitro: effects of 6-dimethylaminopurine
}

\author{
S. Samaké and L. C. Smith* \\ Centre de recherche en reproduction animale, Faculté de médecine vétérinaire, Université de Montréal, \\ Saint-Hyacinthe, PQ J2S 7C6, Canada
}

\begin{abstract}
The methods used to achieve blastomere cell cycle synchronization in embryos used as nuclear donors during embryo reconstruction have been largely unsuccessful. The aim of this study was to determine the reliability of 6-dimethylaminopurine (6-DMAP), an inhibitor of maturation promoting factor, to halt and to synchronize blastomere division in cleavage stage bovine embryos. A second goal was to assess its reversibility and toxicity in vitro. Eight-cell stage embryos obtained at $58 \mathrm{~h}$ after insemination were treated with several concentrations of 6-DMAP for $12 \mathrm{~h}$. Treated embryos were assessed for cleavage arrest, chromatin morphology, DNA synthesis, histone HI and scored for blastocyst formation and for hatching rate. They were subsequently fixed and the number of nuclei counted. Complete arrest of cell division was observed at concentrations of $3 \mathrm{mmol}^{6-D M A P ~}{ }^{-1}$ and above. At these concentrations, interphase nuclei in arrest were noticeably larger compared with interphase nuclei of eight-cell control embryos. Removal from 6-DMAP led to release from cleavage arrest and was followed by synchronized mitosis, histone H1 kinase deactivation and re-entry into interphase within $4-5 \mathrm{~h}$. Twenty-nine per cent of interphase nuclei were synthesizing DNA at the end of the $12 \mathrm{~h}$ treatment as indicated by BrdU analysis. At $2 \mathrm{~h}$ after removal from 6-DMAP, an abrupt decrease to 9\% BrdU-positive nuclei was observed followed by an increase to $39 \%$ by $6 \mathrm{~h}$ and a decrease to $28 \%$ at $10 \mathrm{~h}$. The ability of treated embryos to reach the blastocyst stage in vitro and the number of cells per blastocyst were reduced. These results indicate that 6-DMAP can reversibly arrest and synchronize cleavage to the fifth cell cycle in eight-cell bovine embryos. Although a decrease was observed in the proportion of blastocysts obtained after treatment, it is concluded that 6-DMAP is a useful tool for synchronization studies requiring donor nuclei at metaphase before fusion to recipient oocyte.
\end{abstract}

\section{Introduction}

In mammals, early embryonic processes are characterized by asynchronous cleavage which increases progressively among blastomeres throughout preimplantation development. Asynchronous cleavage appears to play a role in determining the position of blastomeres within the embryo and, in doing so, determines their fate to become inner cell mass (ICM) or trophectoderm (Sutherland et al., 1990). Furthermore, blastomere asynchrony is also believed to cause inconsistent nucleocytoplasmic interactions in embryos reconstructed by nuclear transplantation (NT). The negative effects of the absence of cell cycle stage synchrony between nuclear donor and recipient cytoplasm have been shown to reduce the success of NT procedure in mammals (Smith et al., 1988, 1990; Campbell et al., 1994; Otaegui et al., 1994; Stice et al., 1994). The presence of a high concentration of maturation promoting factor (MPF) in host oocytes enucleated at metaphase is

*Correspondence.

Revised manuscript received 4 November 1996. believed to lead to premature chromosome condensation (PCC) of interphase donor nuclei immediately after fusion (Czolowska et al., 1984; Szöllösi et al., 1986; Collas and Robl, 1991; Collas et al., 1992a). Treatments such as ageing, cooling and activation of recipient oocytes before fusion have been used to reduce MPF activity in enucleated oocytes.

Cell cycle synchronization of blastomeres within donor embryos is more difficult to obtain owing to the high asynchrony observed during late cleavage. Since no reliable methods are currently available for synchronizing cell division of bovine embryos, it was deemed important to determine the effectiveness of different cell-cycle-arresting agents which cause minimal effects to normal development. Nocodazole, an inhibitor of tubulin polymerization, has been used to synchronize mouse embryo cleavage (Kato and Tsunoda, 1992; Otaegui et al., 1994; Samaké and Smith, 1996a, b). Although exposure to nocodazole caused limited toxic effects on subsequent development, chromatin dispersion was evident at longer exposure periods in mouse embryos and so could lead to ploidy abnormalities. An inhibitor of maturation promoting factor (MPF), 6-dimethylaminopurine (6-DMAP) has been used 
to prevent germinal vesicle breakdown (GVBD) during invertebrate (Guerrier and Dorée, 1975; Dorée et al., 1983) and vertebrate oocyte maturation (Rime ef al., 1989). It was also successfully used to arrest cleavage in four-cell mouse embryos, enabling synchronized entry to the fourth cell cycle (Samaké and Smith, 1996a). Therefore, the aim of this study was to determine the lowest concentration of 6-DMAP necessary to arrest cleavage in bovine eight-cell embryos and to establish the reversibility and viability of treated embryos to develop normally to the blastocyst stage after treatment.

\section{Materials and Methods}

\section{Embryo source and culture}

Bovine ovaries were collected at a local abattoir, and non-haemorrhagic follicles with a diameter of $1-5 \mathrm{~mm}$ were punctured with an 18 gauge needle to collect cumulus-oocyte complexes. Groups of 20 cumulus-oocyte complexes with complete cumulus layers and homogeneous ooplasm were collected and matured for $24 \mathrm{~h}$ in $100 \mu \mathrm{l}$ TCM-199 bicarbonate-buffered medium (Gibco, Grand Island, NY) supplemented with $10 \mu \mathrm{g} \mathrm{LH} \mathrm{ml}{ }^{-1}$, I $\mu \mathrm{g} \mathrm{FSH} \mathrm{ml} \mathrm{ml}^{-1}$, $2 \mathrm{ng}$ oestradiol $\mathrm{ml}^{-1}$ and 10\% FCS (Gibco). At the end of maturation, expanded cumulus-oocyte complexes were fertilized by standard protocols (Parrish et al., 1986). Briefly, matured oocytes were transferred to TALP medium containing $10 \mu \mathrm{g}$ heparin $\mathrm{ml}^{-1}$ and inseminated with frozen-thawed, Percoll gradient-separated spermatozoa $\left(1 \times 10^{6}\right.$ spermatozoa $\mathrm{ml}^{-1}$ ). At $18 \mathrm{~h}$ after insemination, zygotes were transferred to $50 \mu \mathrm{l}$ drops of INRA Menezo B2 medium (MB2; Pharmascience, Paris) with bovine oviduct epithelial cells (BOEC) for coculture. Eight-cell stage embryos obtained at $58 \mathrm{~h}$ after insemination were selected for this experiment to test the ability of 6-DMAP to arrest cleavage. Furthermore, to assess the reversibility of 6-DMAP treatment, embryos were washed three times in Hepes-buffered TCM-199 and transferred to agent-free MB2 medium, and their ability to resume cleavages to the fifth cell cycle was determined. They were then assayed, during a period of several hours after release from the arrest agent, to determine the percentage of metaphase nuclei as an indication of timing and synchrony of mitotic division, the activity of histone H1 kinase activity, and the pattern of DNA synthesis. The toxicity of treatment was assessed by washing embryos three times in Hepes-buffered TCM-199 medium and then coculturing them for a further 6 days in agent-free MB2 medium and their ability to resume cleavage and develop into normal blastocysts in vitro was determined.

\section{Cleavage arrest and chromatin morphology assay}

Working solutions of 6-DMAP (Sigma, St Louis, MO) were prepared by appropriate dilution of the stock into TCM-199 medium conditioned with BOEC. Embryos were treated with concentrations ranging from 0 to $5 \mathrm{mmol} \mathrm{ml}^{-1}$ of this agent for $12 \mathrm{~h}$ to determine the lowest effective dose. Some embryos were harvested at different times during the $12 \mathrm{~h}$ treatment to assess the kinetics of changes in chromatin morphology. At the end of treatment, embryos were evaluated for cleavage and chromatin morphology using a rapid staining procedure for nuclei. Briefly, embryos were fixed in $10 \%(\mathrm{v} / \mathrm{v})$ formalin and mounted onto a glass slide in a mounting solution (Mowiol; Aldrich, Milwaukee, WI) containing the DNA-specific dye bisbenzimide at $1 \mu \mathrm{g} \mathrm{ml}{ }^{-1}$ (Hoechst 33342; Sigma). Nuclear morphology and the number of nuclei per embryo were examined with an inverted microscope equipped with epifluorescence (TMD-Diaphot, Nikon) and an ultraviolet filter block $(330-380 \mathrm{~nm}$ excitation and $420 \mathrm{~nm}$ emission; UV-2A, Nikon).

\section{Histone H1 kinase assay}

Protein kinase assays were performed as described by Chesnel and Eppig (1995). Groups of at least ten embryos were collected each hour in $10 \mu \mathrm{l}$ of kinase buffer containing $60 \mathrm{mmol} \quad \beta$-glycerophosphate $1^{-1}, \quad 30 \mathrm{mmol}$ p-nitrophenylphosphate $\quad \mathrm{l}^{-\mathrm{I}}, \quad 25 \mathrm{mmol} \quad 3-[\mathrm{N}$ morpholinolpropanesulfonic acid (MOPS, $\mathrm{pH} 7.2) \mathrm{l}^{-1}$, 15 mmol EGTA $1^{-1}, 15 \mathrm{mmol} \mathrm{MgCl}_{2} \mathrm{l}^{-1}, 0.1 \mathrm{mmol}$ sodium orthovanadate $\left(\mathrm{Na}_{3} \mathrm{VO}_{4}\right) \mathrm{l}^{-1}, 1 \mathrm{mmol}$ DTT $\mathrm{l}^{-1}, 1 \mathrm{mmol}$ PMSF $1^{-1}$, and $1 \mathrm{mg} \mathrm{BSA} \mathrm{ml}^{-1}$ and quickly frozen at $-70^{\circ} \mathrm{C}$. Experiments were performed twice. After thawing, lysates were centrifuged at $14000 \mathrm{~g}$ for $10 \mathrm{~min}$ at $4^{\circ} \mathrm{C}$ before use. Kinase reactions were carried out for $1 \mathrm{~h}$ at $30^{\circ} \mathrm{C}$ in a total volume of $25 \mu \mathrm{l}$ in $\mathrm{H} 1$ kinase buffer supplemented with $100 \mu \mathrm{g}$ histone $\mathrm{HI} \mathrm{ml} \mathrm{m}^{-1}$ (type III-S; Sigma), $2.5 \mathrm{mg}$ myelin basic protein $\mathrm{ml}^{-1}$ (MBP; Sigma), $1 \mu \mathrm{g}$ cAMP-dependent protein kinase $\mathrm{A}$ inhibitor $\mathrm{ml}^{-1}$ (Sigma), and $40 \mu \mathrm{Ci}\left[\mathrm{c}^{32} \mathrm{P}\right] \mathrm{ATP} \mathrm{ml}^{-1}$. Reactions were terminated by adding $25 \mu \mathrm{l}$ of double-strength Laemmli sample buffer (Laemmli, 1970). Phosphorylation of both substrates was analysed by 15\% SDS-PAGE carried out on a horizontal electrophoresis cell (Multiphor II, Pharmacia, Uppsala) attached to a power supply (Multidrive $\mathrm{XL}$; Pharmacia) according to standard methods (Laemmli, 1970). After electrophoresis the gels were fixed for at least $1 \mathrm{~h}$ (two washes) in $50 \%$ methanol $10 \%$ acetic acid, briefly washed in distilled water, dried on Whatman paper sheet at $60^{\circ} \mathrm{C}$ for $90 \mathrm{~min}$ and exposed to $\mathrm{X}$-ray film at $70^{\circ} \mathrm{C}$ for $72 \mathrm{~h}$. The evaluation of histone $\mathrm{H} 1$ phosphorylation was performed by densitometric analysis of the film using a laser densitometer (Ultrascan $\mathrm{XL}$, Pharmacia) with accompanying software (Gelscan XL software Package, Pharmacia). Results are expressed as the ratio of HI kinase activity of treated embryos to control embryos.

\section{DNA synthesis assay}

After release from 6-DMAP, embryos were incubated for $1 \mathrm{~h}$ at each $2 \mathrm{~h}$ interval in Menezo's B2 medium supplemented with $100 \mu \mathrm{mol}$ bromodeoxyuridine $1^{-1}$ (BrdU; 5-bromo-2' deoxyuridine $5^{\prime}$-triphosphate; Sigma) to determine the onset of DNA synthesis over the $10 \mathrm{~h}$ after release. At the end of each incubation period, embryos were fixed in $10 \%(\mathrm{v} / \mathrm{v})$ formalin for 15 min. Plasma membranes were permeabilized in PBS $0.1 \%$ $(\mathrm{v} / \mathrm{v})$ Triton X-100 (Biopharm, Laval, Canada) for $15 \mathrm{~min}$ and embryos were washed in block solution (PBS $3 \%(\mathrm{v} / \mathrm{v}) \mathrm{BSA}$, $0.1 \%(\mathrm{v} / \mathrm{v})$ Tween-20) for $30 \mathrm{~min}$ at room temperature. The 


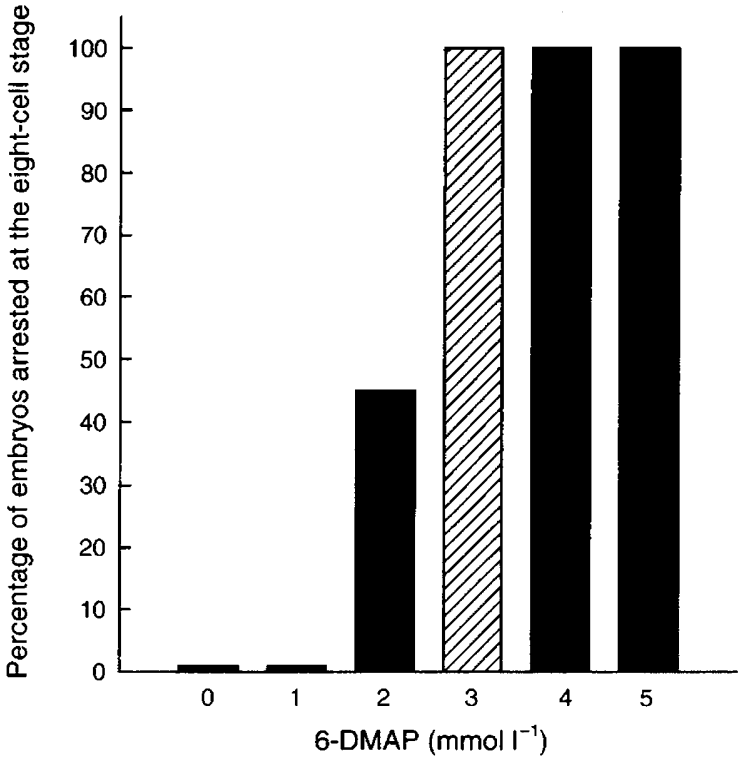

Fig. 1. The ability of 6-dimethylaminopurine (6-DMAP) to induce cleavage arrest in vitro at concentrations of 0 to $5 \mathrm{mmol}^{-1}$ in

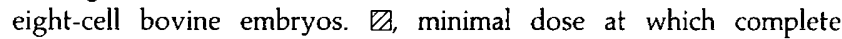
cleavage arrest at eight-cell stage was obtained ( $n=240$ with 20 embryos per concentration in two replicates).

embryos were then incubated for $1 \mathrm{~h}$ in a humidified chamber with $10 \mu \mathrm{l}$ full-strength anti-BrdU monoclonal antibody (Amersham) containing $1 \mu \mathrm{g}$ DNAse $\mathrm{ml}^{-1}$. After incubation, embryos were washed twice in block solution for $10 \mathrm{~min}$ and incubated for $\mathrm{Ih}$ in $10 \mu \mathrm{l}$ fluorescein (DTAF)-conjugated affinity purified goat anti-mouse IgG (Sigma) at 1:100 dilution. The embryos were then washed twice in block solution for $10 \mathrm{~min}$, mounted onto slides in Mowiol containing $1 \mu \mathrm{g}$ Hoechst $33342 \mathrm{ml}^{-1}$ and examined by epifluorescence. Percentages were analysed by the chi-squared test and numbers of cells by ANOVA.

\section{Results}

Complete arrest of cleavage was induced with 6-DMAP in these studies. The effects of the agent with respect to dose required for arrest, reversibility and toxicity are described separately below.

\section{Cell cycle arrest}

Embryos were considered arrested when containing eight nuclei and considered non-arrested when the number of nuclei was greater than eight at the end of treatment. A total of 240 embryos, 40 embryos per concentration, was exposed for $12 \mathrm{~h}$ to concentrations of 6-DMAP ranging from 0 to $5 \mathrm{mmol}^{-1}$. after which they were fixed to assess cleavage arrest and chromatin morphology. Whereas a concentration of $1 \mathrm{mmol}$ 6-DMAP $~^{-1}$ had no effect on cleavage arrest, at $2 \mathrm{mmol} \mathrm{l}^{-1}$ there was cleavage to the fifth cell cycle in $45 \%$ (18/40) of the treated embryos. Complete cell cycle arrest was observed at concentrations of $3 \mathrm{mmol} \mathrm{l}^{-1}$ and above $(P<0.05)$ (Fig. I).

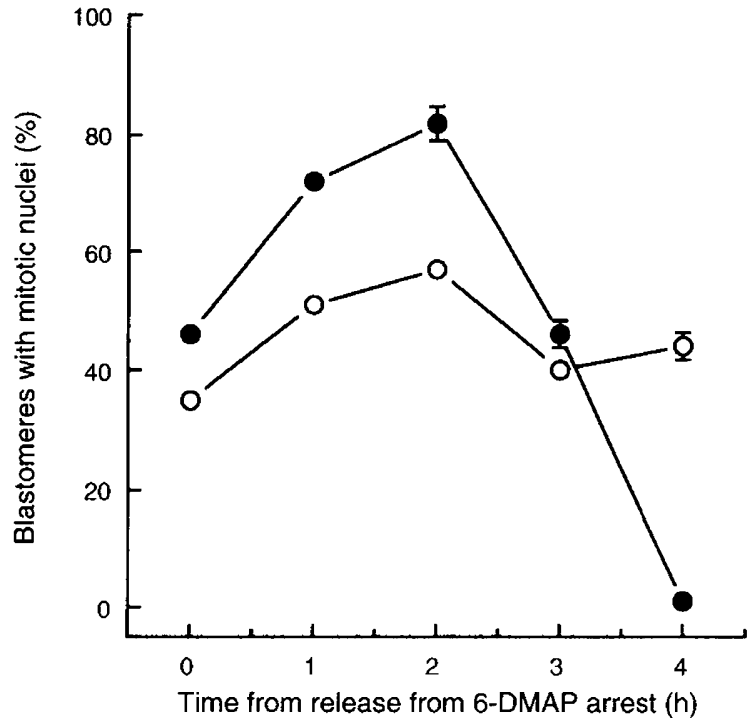

Fig. 2. Cell cycle reversibility of 6-dimethylaminopurine (6-DMAP)treated bovine embryos. Percentage of nuclei found in metaphase at several periods after removal of arrest agent (-) compared with controls $(O)(n=180$ in three replicates).

Ninety per cent of the non-treated control embryos had cleaved within $6 \mathrm{~h}$ after exposure of treated embryos to 6-DMAP, indicating that treated groups were arrested by the cell-cycle-arrest agent $(P<0.05)$.

\section{Reversibility}

The reversibility of 6-DMAP treatment during the period immediately after release from arrest agent was assessed by assaying embryos for the percentage of metaphase nuclei ( $n=180$ embryos), as an indication of the timing and synchrony of mitotic division, histone $\mathrm{HI}$ kinase activity ( $n=206$ embryos) and for DNA synthesis ( $n=240$ embryos). The percentage of nuclei in metaphase increased rapidly after release from the arrest agent, to reach a maximum of $82 \%$ by $2 \mathrm{~h}$ after agent removal, and then decreased rapidly with complete disappearance of metaphase nuclei within $4 \mathrm{~h}$ $(P<0.05)$ (Fig. 2). Although no quantitative assessment was performed on the fixed embryos, an apparent increase in the size of interphase nuclei was observed in all 6-DMAP-treated embryos compared with controls (Fig. 3). Statistical analysis was not possible for the $\mathrm{HI}$ kinase assay; however, there was a noticeable variation in the activity of this kinase. Although absent at the end of treatment, release from 6-DMAP led to an increase in the activity of histone $\mathrm{H} 1$ kinase by $3 \mathrm{~h}$, after which it decreased progressively, with complete disappearance by $5 \mathrm{~h}$ (Fig. 4a, b). The timing and synchrony of entry into S-phase were assessed by removing embryos from 6-DMAP and assaying for $\mathrm{BrdU}$ incorporation at $2 \mathrm{~h}$ intervals for the following $10 \mathrm{~h}$ (Fig. 5). At the end of treatment $29 \%$ of blastomeres were still incorporating $\mathrm{BrdU}$, indicating continued DNA synthesis. This amount of DNA synthesis decreased abruptly to $9 \%$ by $2 \mathrm{~h}$, then increased gradually during the next 

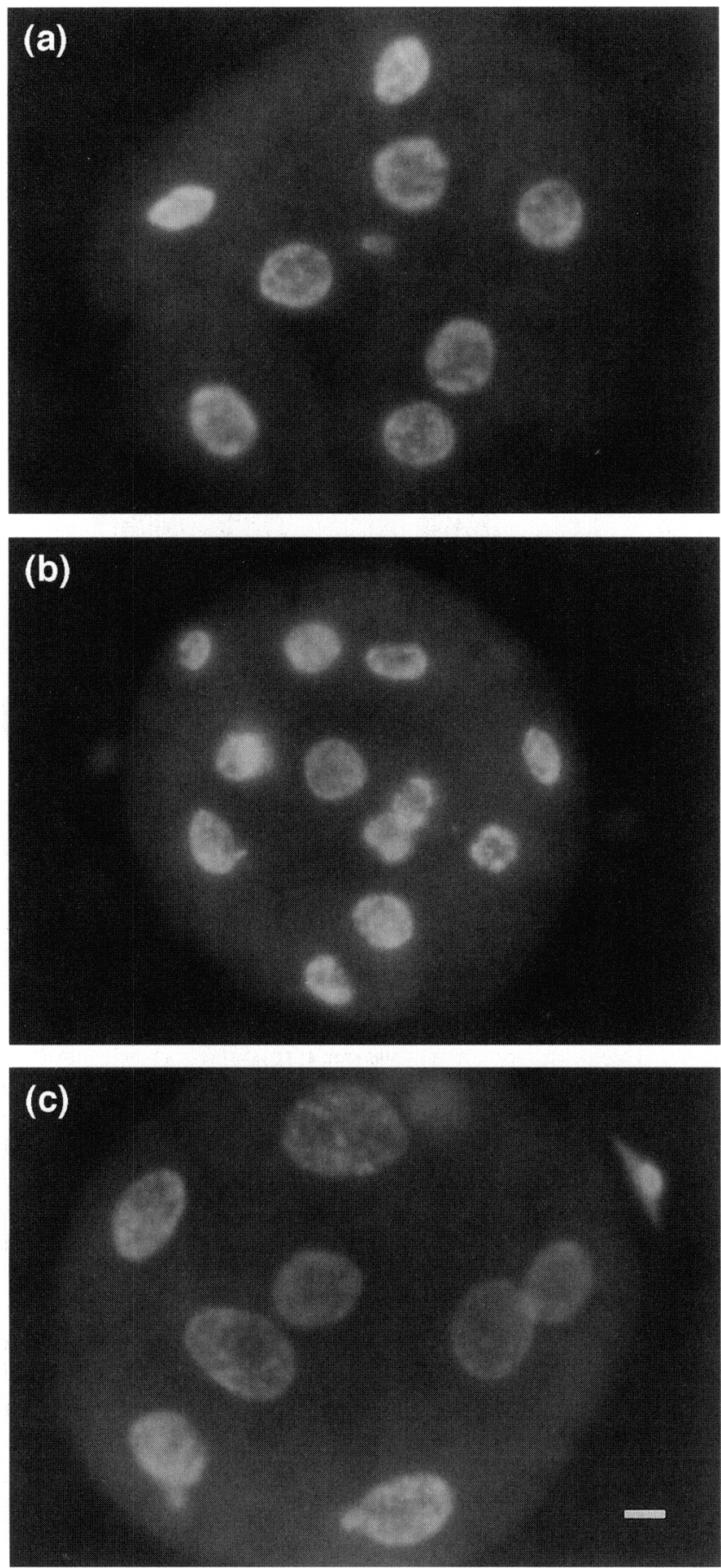

Fig. 3. Chromatin morphology of eight-cell bovine embryos (a) before exposure to 6-dimethylaminopurine (6-DMAP), (b) control after $12 \mathrm{~h}$ (70 h after insemination) and (c) after $12 \mathrm{~h}$ exposure to 3 mmol 6-DMAP $\mathrm{I}^{-1}$. Scale bar represents $10 \mu \mathrm{m}$.

$4 \mathrm{~h}$, reaching a maximum of $39 \%$ by $6 \mathrm{~h}$, and then decreased to $28 \%$ by $10 \mathrm{~h}$ after removal of 6 -DMAP $(P<0.05)$. Since BrdU incorporation oscillated during the same period in control embryos, it is unknown whether 6-DMAP treatment had any effect on the synchrony of re-entry into the following S-phase. (a)

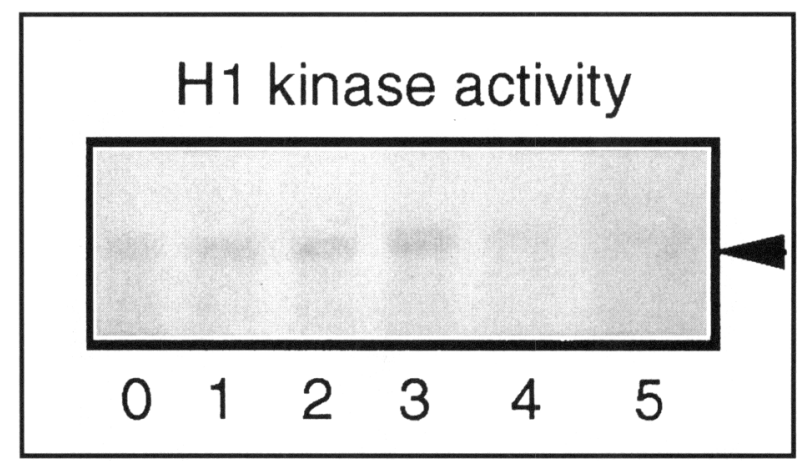

(b)

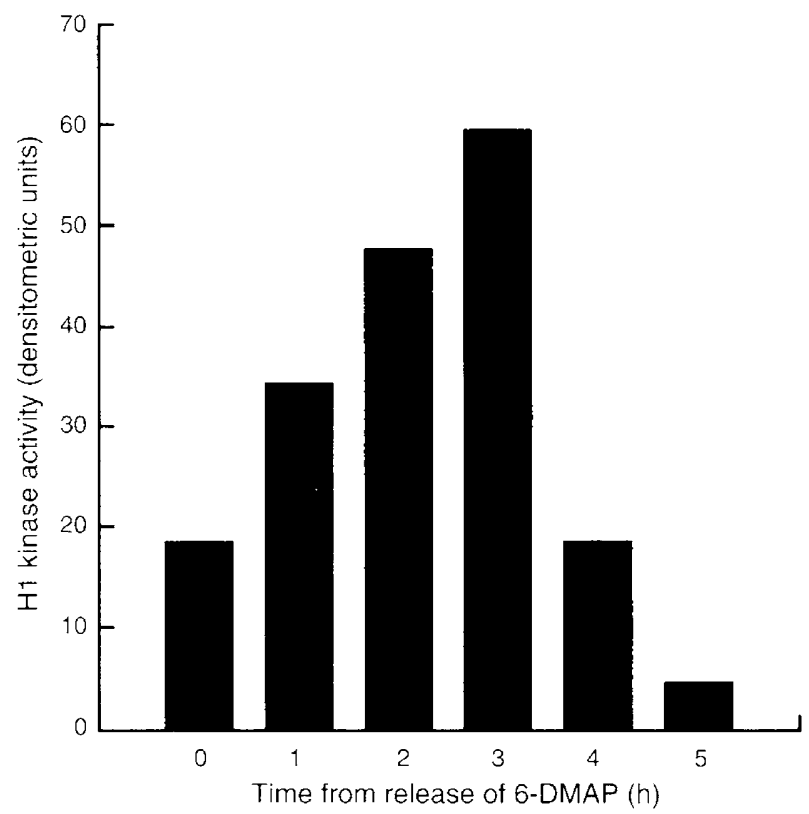

Fig. 4. Histone $H$ I kinase assay showing (a) representative autoradiogram of gel showing phosphorylation of histone $\mathrm{HI}$ by eight-cell bovine embryos $5 \mathrm{~h}$ after release from $12 \mathrm{~h}$ treatment with 6-dimethylaminopurine (6-DMAP), and (b) densitometric readings of autoradiogram showing histone $\mathrm{H} 1$ kinase activity of embryos treated with 6-DMAI. Scale is arbitrary.

Toxicity

The toxicity of 6-DMAP on embryo development in vitro was assessed by exposing 180 eight-cell treated embryos for $12 \mathrm{~h}$ to $0-5 \mathrm{mmol} \mathrm{I}^{-1}$ of the agent, then washing and culturing them in agent-free MB2 medium for a further 6 days (Fig. 6). All concentrations used in this study, including the minimal effective dose of $3 \mathrm{mmol}]^{\text {' }}$, significantly reduced the ability of treated embryos to develop to the blastocyst stage $(P<0.05)$. A significant reduction in the number of cells in blastocysts compared with controls was also observed $(P<0.05)$. Furthermore, this toxic effect increased significantly for concentrations above $3 \mathrm{mmol} 1^{-1}$ $(P<0.05)$. Hatching rate per blastocyst at day 6 was not affected in the presence of the minimal effective dose of $3 \mathrm{mmol} \mathrm{l}^{-1}$ relative to controls $(P>0.05)$ (Fig. 6b). However, 


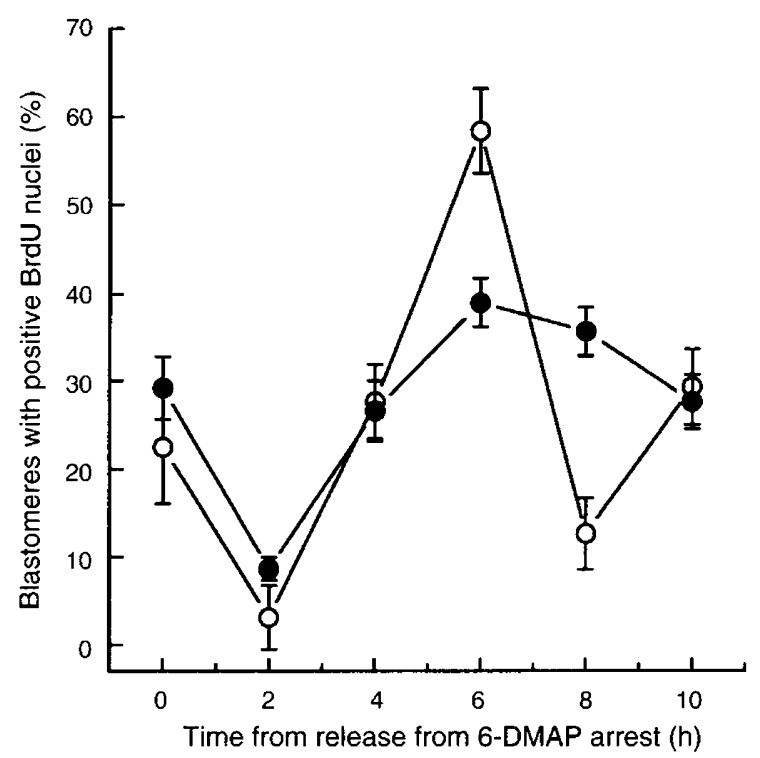

Fig. 5. Percentage of blastomeres positively showing BrdU incorporation in 6-DMAP-treated embryos several hours after removal of agent (O) compared with controls $(O)(n=240$ with 20 embryos $\mathrm{h}^{-1}$ in two replicates).

hatching rate was significantly reduced for concentrations above $3 \mathrm{mmol} \mathrm{l}^{-1}(P<0.05)$.

\section{Discussion}

Our results indicate that bovine eight-cell embryo cleavage can be successfully and reversibly arrested for up to $12 \mathrm{~h}$ by 6-DMAP treatment at $3 \mathrm{mmol} \mathrm{l}^{-1}$, but with a decrease of its subsequent development in vitro to the blastocyst stage. Furthermore, release from 6-DMAP led to synchronized entry into mitosis, as confirmed by the appearance of histone $\mathrm{HI}$ kinase activity by $1 \mathrm{~h}$ and by the increase of metaphase nuclei of blastomeres within $2 \mathrm{~h}$. These blastomeres progressed through mitosis over $2 \mathrm{~h}$ and subsequently exited from $\mathrm{M}$-phase to enter into interphase of the fifth cell cycle. This was confirmed by the decrease of metaphase after $1 \mathrm{~h}$ and histone $\mathrm{H} 1$ kinase activity through $4 \mathrm{~h}$, and the complete disappearance of these two characteristics within $4 \mathrm{~h}$ and $5 \mathrm{~h}$, respectively. These observations confirm that the activity of 6-DMAP on cleavage arrest of eight-cell bovine embryos is reversible for up to $12 \mathrm{~h}$.

In this study, a mimimum dose of $3 \mathrm{mmol}^{-1}$ was required for 6-DMAP to successfully and reversibly arrest eight-cell bovine embryos at interphase; a similar dose was required for this agent to arrest four-cell mouse embryos at interphase (Samaké and Smith, 1996a). However, a lower concentration ( $2 \mathrm{mmol}$ ) has been shown to prevent germinal vesicle breakdown (GVBD) of mouse (Rime et al., 1989) and bovine oocytes (Fulka et al., 1991). By preventing the normal phosphorylation of proteins, 6-DMAP interferes with the activity of MPF, and consequently prevents cell division (Néant et al., 1988a, 1989; Rime et al, 1989). MPF cyclic activity has been shown to control the M-phase in somatic and germinal cells (Masui and Markert, 1971, Gerhart et al., 1984; Newport and Kirschner,
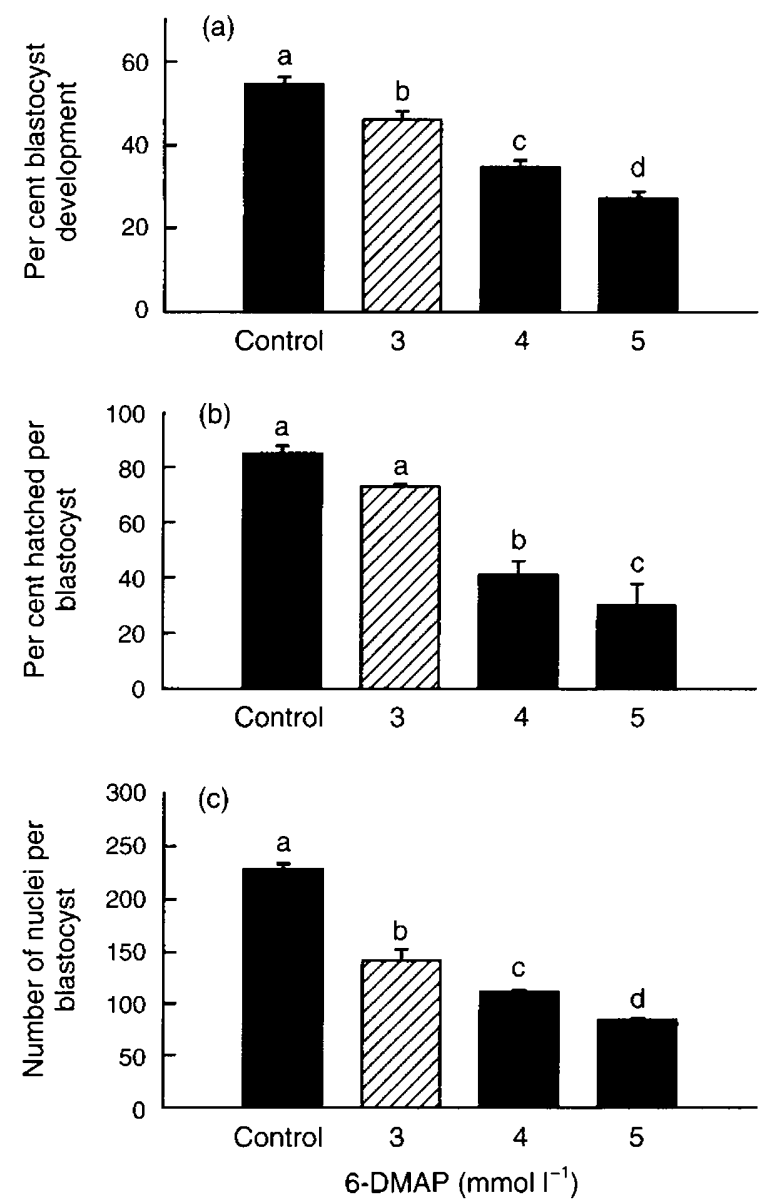

Fig. 6. Effects of 6-dimethylaminopurine (6-DMAP) at doses of 0 to $5 \mathrm{mmol}^{-1}$ on (a) the development in vitro of eight-cell bovine embryos to the blastocyst stage, (b) the hatching rate, and (c) the number of nuclei at day 6 after removal of the agent $(n=180$ with 15 embryos per concentration in three replicates). $\square$, effects using the minimal effective dose of 3 mmol o-DMAP $~^{-1}$. Columns with different letters above are significantly different from one another $(P<0.05)$.

1984). Although the ability of 6-DMAP to arrest cleavage was predictable, it remains unclear why arrest of embryos occurs at higher concentrations $\left(3 \mathrm{mmol} \mathrm{I}^{-1}\right)$ compared with that of oocytes $\left(2 \mathrm{mmol} \mathrm{l} \mathrm{l}^{-1}\right)$. It is possible that the autonomous nature of cleavage in amphibian (Newport, Kirschner, 1982) as well as in mammalian early embryos (Waksmundzka et al., 1984) leads to a requirement for increased concentrations of 6-DMAP to induce cell cycle arrest.

Since 6-DMAP inhibits the normal phosphorylation of proteins, it is expected that blastomeres of treated embryos would be arrested at late G2 of the cell cycle, just before the rise of MPF activity. However, in this study, $29 \%$ of arrested blastomeres were incorporating $\mathrm{BrdU}$ and thus synthesizing DNA at the end of 6-DMAP treatment. Although the mechanisms for this phenomenon are unknown, one possible interpretation of these results is that some blastomeres may remain in S-phase instead of terminating replication and arresting in G2-phase. A further observation of the present study was that blastomere nuclei in embryos treated with 6-DMAP appeared larger compared with control embryos. However, quantitative measurements were not performed 
owing to possible artifacts caused by blastomere squashing during the whole-mount technique. Large nuclei have also been reported after exposure to 6-DMAP in oocytes and embryos of molluscs (Néant et al., 1988b, 1994), echinoderms (Néant et al., 1989; Dufresne et al., 1991) and mice (Rime ef al., 1989; Szöllösi et al., 1991; Samaké and Smith, 1996a). In invertebrate oocytes, nuclear enlargement has been shown to be due to the decondensation of metaphase chromatin, which merges to produce large DNA-synthesizing nuclei (Néant et al., 1988b, 1994; Dubé and Dufresne, 1990). None the less, a recent report using three marine invertebrates has shown that the regulation of DNA replication of the first mitotic division after fertilization and activation remain intact in the presence of 6-DMAP (Néant and Dubé, 1996).

Although we conclude that the mitotic arrest activity of 6-DMAP on eight-cell bovine embryo cleavage with synchronized entry of blastomeres into mitosis is reversible, the ability of treated embryos to develop to the blastocyst stage and the number of cells per blastocyst are reduced by this agent compared with controls. In mice (Samaké and Smith, 1996a) and in bovine embryos in the current study, DNA synthesis was observed during and at the end of 6-DMAP treatment. The toxicity of this agent to both mouse and bovine embryo viability may have been related to ploidy defects caused by continuous DNA synthesis after long periods of exposure to 6-DMAP. Alternatively, the observed lower cell numbers may have resulted from the $12 \mathrm{~h}$ arrest present in treated but not in control groups. Experiments in which these 6-DMAP-treated bovine blastocysts will be transferred to synchronized recipients will help to assess the potential for long term toxicity on embryo viability.

The importance of synchrony between the donor and recipient cell cycle stages in embryo reconstitution studies by nuclear transfer has been well established in several species (Smith et al., 1988, 1990; Collas et al., 1992a, b; Barnes et al., 1993; Campbell et al., 1993, 1994; Cheong et al., 1993; Otaegui et al., 1994; Stice et al., 1994). Our results indicate that 6-DMAP can be used to synchronize nuclear donor cells at late G2-phase before fusion. The fully reversible activity of 6-DMAP makes it a useful choice for studies on cell cycle reversibility. Furthermore, in contrast to nocodazole, synchronization of donor cells at metaphase can be achieved with 6-DMAP as early as $2 \mathrm{~h}$ after release from the arrest agent. This synchronization is useful when nuclei are required at this specific cell cycle stage prior to fusion to recipient oocytes. The opportunity to obtain such nuclear donor cells will enable further studies on the effects of nucleocytoplasmic asynchrony and its relevance to embryo cloning procedures.

The authors thank C. Léveillée and L. Moquin for excellent technical assistance, D. McLay and $\mathrm{H}$. Clarke for help with DNA synthesis technique, A. K. Goff for aid in data analysis and B. D. Murphy for his critical review of the manuscript. Funded by CORPAQ and NSERC of Canada.

\section{References}

Barnes FL, Collas P, Powell R, King WA, Westhusin M and Shepherd D (1993) Influence of recipient oocyte cell cycle stage on DNA synthesis, nuclear envelope breakdown, chromosome constitution, and development in nuclear transplant bovine embryos Molecular Reproduction and Development 36 33-41

Campbell KHS, Ritchie WA and Wilmut I (1993) Nuclear-cytoplasmic interactions during the first cell cycle of nuclear transfer reconstructed bovine embryos: implications for deoxyribonucleic acid replication and development Biology of Reproduction 49 933-942

Campbell KHS, Loi P, Cappai P and Wilmut I (1994) Improved development to blastocyst of ovine nuclear transfer embryos reconstructed during the presumptive S-phase of enucleated activated oocytes Biology of Reproduction 50 1385-1393

Cheong HT, Takahashi $Y$ and Kanagawa $H$ (1993) Birth of mice after transplantation of early cell cycle stage embryonic nuclei into enucleated oocytes Journal of Reproduction and Fertility $\mathbf{4 8}$ 958-963

Chesnel F and Eppig JJ (1995) Induction of precocious germinal vesicle breakdown (GVB) by GVB-incompetent mouse oocytes: possible role of mitogen-activated protein kinases rather than p34cdc2 kinase Biology of Reproduction 52 895-902

Collas P and Robl JM (1991) Relationship between nuclear remodeling and development in nuclear transplant rabbit embryos Biology of Reproduction 45 455-465

Collas P, Basile JJ and Robl JM (1992a) Influence of cell cycle stage of the donor nucleus on development of nuclear transplant rabbit embryos Biology of Reproduction 46 492-500

Collas P, Pinto-Correia C, DeLeon FAP and Robl JM (1992b) Effect of donor cell cycle stage on chromatin and spindle morphology in nuclear transplant rabbit embryos Biology of Reproduction 46 501-511

Czolowska R, Modlinski JA and Tarkowski AK (1984) Behaviour of thymocyte nuclei in non-activated and activated mouse oocytes Journal of Cell Science 69 19-34

Dorée M, Peaucellier G and Picard A (1983) Activity of the maturation promoting factor and the extent of the protein phosphorylation oscillate simultaneously during meiotic maturation of starfish oocytes Developmental Biology 99 489-501

Dubé F and Dufresne L (1990) Release of metaphase arrest by partial inhibition of protein synthesis in blue mussel oocytes Journal of Experimental Zoology $256323-332$

Dufresne I, Néant I, Saint-Pierre J, Dubé F and Guerrier P (1991) Effects of 6-dimethylaminopurine on microtubules and putative intermediate filaments Journal of Cell Science 99 721-730

Fulka JJ, Leibfried-Rutledge and First, NL (1991) Effect of 6-dimethylaminopurine on germinal vesicle breakdown of bovine oocytes Molecular Reproduction and Development 29 379-384

Gerhart JC, Wu M and Kirschner MW (1984) Cell dynamics of an M-phasespecific cytoplasmic factor in Xenopus laevis oocytes and eggs Journal of Cell Biology 98 1247-1255

Guerrier P and Dorée M (1975) Hormonal control of reinitiation of meiosis in starfish. The requirement of 1 -methyladenine during nuclear maturation Developmental Biology $47341-348$

Kato $Y$ and Tsunoda $Y$ (1992) Synchronous division of mouse two-cell embryos with nocodazole in vitro. Journal of Reproduction and Fertility 95 39-43

Laemmli UK (1970) Cleavage of structural proteins during the assembly of the head of bacteriophage T4 Nature 277 680-685

Masui Y and Markert CL (1971) Cytoplasmic control of nuclear behaviour during meiotic maturation of frog oocytes Journal of Experimental Zoology $177 \quad 129-146$

Néant I and Dubé F (1996) DNA replication initiation by 6-DMAP treatment in maturing oocytes and dividing embryos from marine invertebrates Molecular Reproduction and Development 44 443-451

Néant I and Guerrier P (1988a) 6-Dimethylaminopurine blocks starfish oocyte maturation by inhibiting a relevant protein kinase activity Experimental Cell Research 176 68-79

Néant 1 and Guerrier P (1988b) Meiosis reinitiation in the mollusc Patella vulgata: regulation of MPF, CSF and chromosome condensation activity by intracellular $\mathrm{pH}$, protein synthesis and phosphorylation Development $\mathbf{1 0 2}$ 505-516

Néant I, Charbonneau M and Guerrier P (1989) A requirement for protein phosphorylation in regulating the meiotic and mitotic cell cycles in echinoderms Developmental Biology 132 304-314

Néant I, Dufresne L, Morasse J, Gicquaud C, Guerrier P and Dubé F (1994) The release from metaphase arrest in blue mussel oocytes International Journal of Developmental Biology 38 513-523 
Newport J and Kirschner M (1982) A major developmental transition in early Xenopus embryos. I. Characterization and timing of cellular changes at the midblastula stage Cell $\mathbf{3 0} 675-686$

Newport JW and Kirschner MW (1984) Regulation of the cell cycle during Xenopus laevis development Cell 37 731-742

Otaegui PJ, O'Neill GT, Campbell KHS and Wilmut I (1994) Transfer of nuclei from 8-cell stage mouse embryos following use of nocodazole to control the cell cycle Molecular Reproduction and Development 39 147-152

Parrish JJ, Susko-Parrish JL, Leibfried Rutledge ML, Critser ES, Eyestone WH and First NL (1986) Bovine in vitro fertilization with frozen-thawed semen Theriogenology 25 591-600

Rime H, Neant I, Guerrier P and Ozon R (1989) 6-Dimethylaminopurine (6-DMAP), a reversible inhibitor of the transition to metaphase during the first meiotic cell division of the mouse oocyte Developmental Biology 133 $169-179$

Samaké S and Smith LC (1996a) Effects of cell-cycle-blocking drugs on cleavage and development of preimplantation mouse embryos fournal of Experimental Zoology 274 111-120

Samaké S and Smith LC (1996b) Synchronization of cell division in eight-cell bovine embryos produced in vitro: effects of nocodazole Molecular Reproduction and Development 44 486-492
Smith LC, Wilmut I and Hunter RH (1988) Influence of cell cycle stage at nuclear transplantation on the development in vitro of mouse embryos journal of Reproduction and Fertility 84 619-624

Smith LC, Wilmut I and West JD (1990) Control of first cleavage in single-cell reconstituted mouse embryos Joumal of Reproduction and Fertility 88 655-663

Stice SL, Keefer CL and Matthews L (1994) Bovine nuclear transfer embryos: oocyte activation prior to blastomere fusion Molecular Reproduction and Development 38 61-68

Sutherland AE, Speed TP and Calarco PG (1990) Inner cell allocation in the mouse morula: the role of oriented division during fourth cleavage Developmental Biology 137 13-25

Szöllösi D, Czolowska R, Soltynska MS and Tarkowski AK (1986) Remodelling of thymocyte nuclei in activated mouse oocytes: an ultrastructural study European Journal of Cell Biology 42 140-15I

Szöllösi MS, Debey P, Szsllssi D, Rime H and Vautier D (1991) Chromatin behaviour under influence of puromycin and 6-DMAP at different stages of mouse oocyte maturation Chromosoma 100 339-354

Waksmundzka M, Krysiak E, Karasiewicz J, Czolowska R and Tarkowski AK (1984) Autonomous cortical activity in mouse eggs controlled by cytoplasmic clock Journal of Embryology and Experimental Morphology 79 77-96 